\title{
Evaluation of the knowledge of postoperative pain among participants of a virtual scientific journey in Anesthesiology
}

\author{
Avaliação do conhecimento de dor pós-operatória entre participantes em jornada científica \\ virtual em Anestesiologia
}

Fernando Souza Lopes ${ }^{1}$, Anaisa Caparroz Duarte¹, Pablo Braga Gusman², Diógenes Silva³, Eliana Marisa Ganem¹, Guilherme Antônio Moreira de Barros ${ }^{1}$

DOI 10.5935/1806-0013.20160026

\section{ABSTRACT}

BACKGROUND AND OBJECTIVES: Postoperative pain still undertreated, which is associated to increased morbidity and mortality. This study aimed at evaluating the knowledge of physicians participating in a virtual journey in Anesthesiology. Anesthesiologists are professionals often involved with postoperative pain management.

METHODS: Five hundred participants of a virtual journey in Anesthesiology were invited to answer a questionnaire available in SurveyMonkey website on specific knowledge of postoperative pain and its management.

RESULTS: The questionnaire was answered by 136 individuals and, according to $94.86 \%$ of them, postoperative pain management may decrease the incidence of chronic postoperative pain. For $72(52.95 \%)$ participants, postoperative pain is adequately managed in their workplaces. For 71 participants, more than $50 \%$ of patients refer postoperative pain. Excluding fear of anesthesia, major concerns of patients, according to 49.26 and $37.5 \%$ of respondents, is fear of feeling pain during surgery and after surgery, respectively. For 74 (75\%) participants, analgesic prescription "as needed" should be avoided for postoperative pain.

CONCLUSION: In general, participants of the virtual journey are not familiar with the problems of postoperative pain, probably due to their limited contact with hospitalized patients. These deficiencies may be solved with ongoing education and and improvements in the medical school curricula and residency programs.

Keywords: Acute pain, Anesthesiology, Knowledge.

1. Universidade Estadual Paulista, Faculdade de Medicina de Botucatu, Departamento de Anestesiologia, Botucatu, SP, Brasil.

2. Hospital Meridional, Departamento de Anestesiologia, Vitória, ES, Brasil.

3. Departamento de Inovaçấo e Desenvolvimento da Anestech, Florianopolis, SC, Brasil.

Submitted in February 29, 2016.

Accepted for publication in May 25, 2016

Conflict of interests: none - Sponsoring sources: none.

Correspondence to:

Avenida Professor Mário Rubens Guimarăes Montenegro, s/nº

18618-687 Botucatu, SP, Brasil.

E-mail: barros@fmb.unesp.br

(c) Sociedade Brasileira para o Estudo da Dor

\section{RESUMO}

JUSTIFICATIVA E OBJETIVOS: A dor pós-operatória continua sendo subtratada, o que está associado ao aumento de morbimortalidade. O objetivo deste estudo foi avaliar o conhecimento de médicos que se inscreveram em jornada virtual em Anestesiologia. $\mathrm{O}$ anestesiologista é profissional frequentemente envolvido no tratamento da dor pós-operatória.

MÉTODOS: Quinhentos participantes de uma jornada virtual em Anestesiologia foram convidados a responder a questionário disponível no site SurveyMonkey sobre conhecimentos específicos em dor pós-operatória e o seu tratamento.

RESULTADOS: Responderam ao questionário 136 indivíduos e, segundo a opiniáo de $94,86 \%$ deles, o tratamento da dor pósoperatória pode diminuir a incidência da dor pós-operatória persistente. Para 72 participantes $(52,95 \%)$ a dor pós-operatória é bem tratada onde atuam. Para 71 participantes, mais de $50 \%$ dos pacientes apresentam dor pós-operatória. Excluindo o medo do ato anestésico, os maiores temores dos pacientes, segundo resposta de 49,26 e 37,5\% dos entrevistados, é o de sentir dor durante a realização do procedimento cirúrgico e após a realização da cirurgia, respectivamente. Para $74,(75 \%)$ participantes a prescrição "se necessário" de analgésicos deve ser evitada na dor pós-operatória.

CONCLUSÁO: Os participantes da jornada virtual, de modo geral, têm pouco conhecimento da problemática da dor pósoperatória, provavelmente em decorrência do seu pouco contato com os pacientes internados. Essas deficiências podem ser sanadas com a educação continuada, assim como com melhorias dos programas de graduação e residências em medicina.

Descritores: Anestesiologia, Conhecimento, Dor aguda.

\section{INTRODUCTION}

Acute pain is defined as a self-limited process of spontaneous resolution. This in general happens within days or weeks and in most cases the reason for pain can be identified. Major example of acute pain is postoperative pain which is still undermanaged in spite of all phytopathological and therapeutic knowledge obtained in the last decades ${ }^{1-4}$. It is known that postoperative analgesia improves patients' prognosis, reason why adequate postoperative care and analgesia are appreciated ${ }^{4}$.

Postoperative pain (POP), when not adequately managed, 
may have noxious consequences and be associated to more postoperative complications which in turn result in more morbidity and mortality ${ }^{3,5-8,11}$ and may delay pulmonary function recovery and impair ambulation, increase the incidence of nausea and vomiting, increase peripheral vascular resistance and myocardial oxygen consumption and, as a consequence, hospital $\operatorname{costs}^{2,3,5,7,12,13}$. In spite of this, studies carried out in the United States have shown that more than $75 \%$ of surgical patients had POP of different intensities ${ }^{9,10}$.

So, POP analgesia should aim at minimizing or abolishing discomfort, at helping recovery process, at preventing or treating adverse effects associated to therapy and at making treatment economically feasible ${ }^{13-15}$.

So, it is justifiable to evaluate knowledge and behaviors of anesthesiologists with regard to this type of pain. In the absence of reliable Brazilian data on the subject, data obtained from the sample of physicians enrolled in an Anesthesiology journey may be useful to the development of strategies aiming at minimizing complications and inadequate POP management.

This study aimed at evaluating the knowledge of Brazilian residents and anesthesiologists enrolled in a virtual Anesthesiology journey contemplating POP management.

\section{METHODS}

Five hundred individuals enrolled in the "II Virtual Journey in Anesthesiology" (http://anestesiavirtual.com.br), among them graduated anesthesiologists and residents in Anesthesiology, were invited to participate in the survey. Those agreeing to participate have signed the consent term for the use of database (CTUDB).

By means of e-mail messages, participants were asked to answer a virtual questionnaire available in the SurveyMonkey website (surveymonkey.com). This questionnaire was made up of multiple choice questions contemplating participants' knowledge about POP and its management (Attachment 1). Answers were extracted with tools available in the SurveyMonkey website and then analyzed. Results are expressed in mean \pm standard deviation (SD), median, percentages or frequencies, when adequate.

This study was approved by the Research Ethics Committee of the Institution (Opinion CEP 268.540).

\section{RESULTS}

Among 500 physicians invited to participate in the survey, 146 agreed that their answers were included in the database. When asked about the percentage of ambulatory surgical procedures performed in their workplace(s), $55.1 \%$ have answered that $1 / 5$ are ambulatory procedures (Figure 1). Ninety-five percent of respondents believe that POP is well managed in their institutions; while $21.6 \%$ have stated that $80 \%$ of patients have POP (Figure 2).

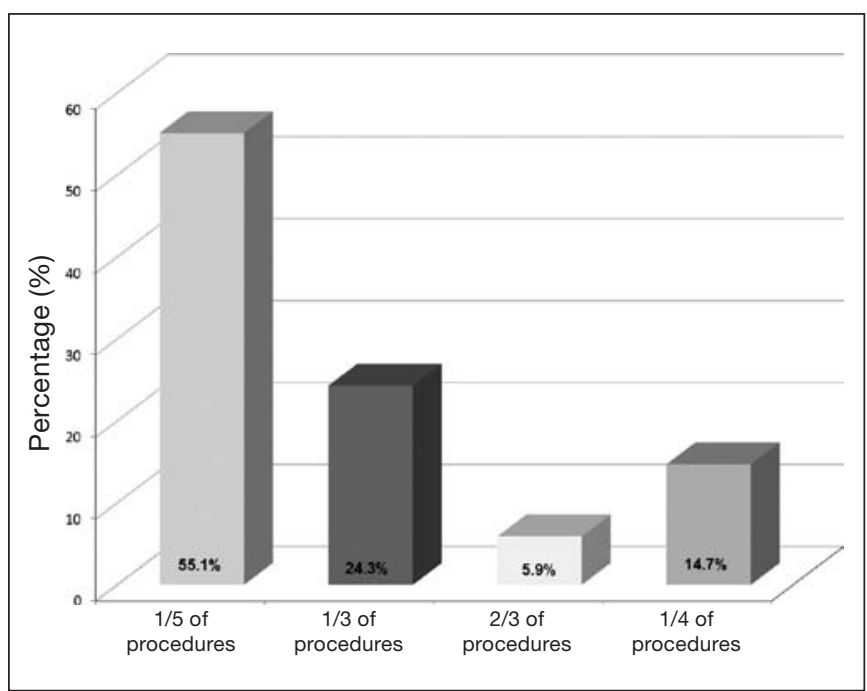

Figure 1. Percentage of ambulatory surgical procedures in the workplace(s) of respondents $(n=146)$

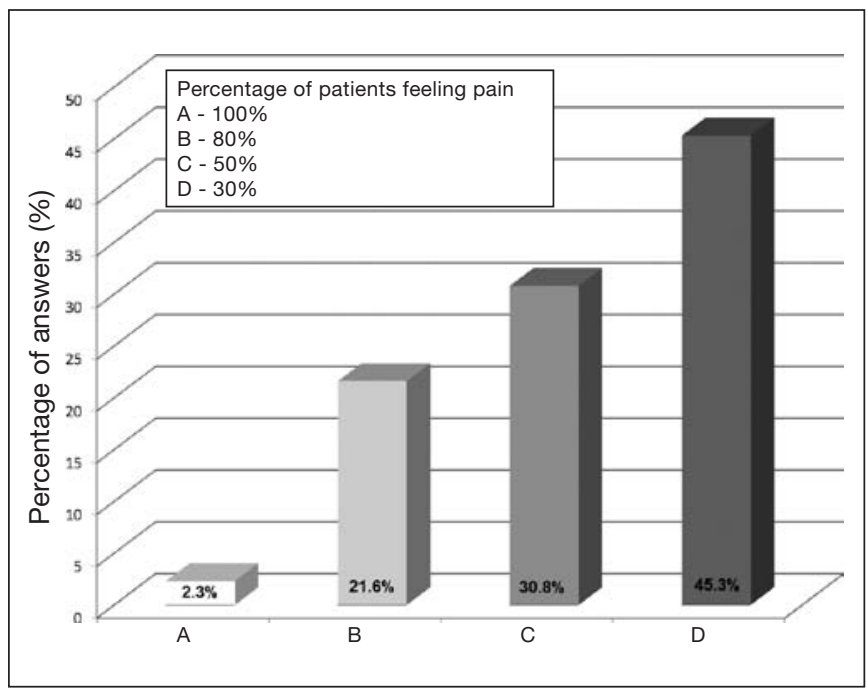

Figure 2. Respondents estimates of the percentage of patients feeling pain in their workplace(s) $(n=146)$

When asked about the incidence of chronic postoperative pain (CPOP), only $23.7 \%$ of respondents recognized that acute pain management potentially decreases its incidence. Among surgeries with the highest incidence of CPOP, respondents have correctly pointed to limb amputation $(51.8 \%)$ and thoracotomy (36.7\%).

Excluding fear of anesthesia, major fear of patients before being submitted to surgery is, according to $39 \%$ of respondents, feeling pain after surgery. According to most respondents $(50 \%)$, their patients fear feeling pain during surgery. Other concerns pointed by respondents were "vomiting" (6.2\%) and "not getting better from the disease which is the reason for the surgery" (2.7\%).

According to $84.9 \%$ of respondents, postoperative ileus is not a challenge during POP management, while $91.8 \%$ of them consider walking as the most important factor responsible for decreasing the time needed to reestablish gastrointestinal motility. 
Table 1. Opinion with regard to the statement "With regard to the use 'if needed' of analgesics one may state"

\begin{tabular}{lcc}
\hline Statements & $\begin{array}{c}\text { Percentage of answers } \\
\text { Total of answers among } \\
146 \text { respondents }\end{array}$ & $\begin{array}{c}79.8 \\
116 \\
\text { Should be avoided for acute pain }\end{array}$ \\
Should only be used for opioid prescription & 14 & 3.1 \\
It just offers the dose needed by the patient, that is why it is safer and more effective & 3.1 & 5 \\
Should be the choice to treat acute pain & 100 & 5 \\
Total & 146 \\
\hline
\end{tabular}

Table 2. Answers to the question "Which should be the first analgesic drug to be remembered for postoperative pain management"?

\begin{tabular}{lcc}
\hline Category of analgesics & Percentage & Total answers \\
\hline Non-opioid and non anti-inflammatory analgesic (e.g., dipirone) & 48.8 & 72 \\
Strong opioids (e.g. morphine) & 24.8 & 36 \\
Weak opioids (e.g. tramadol) & 13.9 & 20 \\
Non-selective non-steroid anti-inflammatory drug & 7 & 10 \\
Non-steroid selective Cox-2 inhibitor anti-inflammatory drug (e.g. parecoxibe) & 4 & 6 \\
Others & 1.5 & 2 \\
Total & 100 & 146 \\
\hline
\end{tabular}

Table 3. Results of the question "Which administration route you consider the most effective to manage acute pain"?

\begin{tabular}{lcc}
\hline Administration route & Percentage & Total answers of 146 respondents \\
\hline Intravenous & 52.0 & 76 \\
Locoregional blocks & 22.4 & 37 \\
Epidural & 13.7 & 20 \\
Spinal & 8.2 & 12 \\
Oral & 0.7 & 1 \\
Total & 100 & 146 \\
\hline
\end{tabular}

When choosing analgesics and doses to manage POP, 96\% of respondents consider important to evaluate patients' physical status, in addition to surgical size and incision topography. For most of them (79.8\%), analgesic prescription "if needed" should be avoided in POP management (Table 1). Table 2 shows frequencies in which different categories of analgesics are remembered when managing POP.

For $52 \%$ of respondents, most effective administration route for managing POP is intravenous (Table 3). Seventy-one percent of respondents are experienced in handling patientcontrolled analgesia (PCA) devices being that for $30.2 \%$ of them intravenous route is the only to be used for PCA. Continuous analgesic infusion associated to demand doses in PCA pumps is considered the safest analgesia method by $85 \%$ of respondents.

\section{DISCUSSION}

There are still no accurate Brazilian data on the incidence of acute pain, especially POP, as well as on its consequences for patients. However, this type of pain may be considered a public health problem since, according to international data, it is present in more than $75 \%$ of patients ${ }^{10}$.

It is estimated that more than 43 million North-Americans are annually exposed to $\mathrm{POP}^{6}$. Between 1996 and 2006 there has been $300 \%$ increase in the number of surgical procedures performed in the ambulatory, while the number of hospitalizations has remained virtually the same ${ }^{16}$. This makes ambulatory procedures currently responsible for a large number of surgeries performed in that country.

With regard to Brazilian reality, based on reports of participants in this study, it was observed that ambulatory procedures are approximately $20 \%$ of total procedures performed by those answering this survey. Patients submitted to ambulatory procedures are those at higher risk of having POP, because they become more vulnerable after hospital discharge. This is due to the fact that they no longer count on around-the-clock professional support to supply their need for analgesia after hospital discharge", although one criterion to discharge patients back home is adequate analgesia ${ }^{17}$. However, analgesia is often obtained with prescription of opioids, drugs with short half-life and which in general do not maintain patients painless after hospital discharge.

Another concern is CPOP which is more common in some types of surgery ${ }^{7,13,18}$. In our survey, respondents have correctly pointed, among options, that amputation is a surgery with higher incidence of chronicity. According to the literature, 30 to $85 \%$ of limb amputations evolve with $\mathrm{CPOP}^{7}$. 
Thoracotomy is the second more frequently evolving with CPOP (5-65\%), being mastectomy the third (11-57\%), among other procedures ${ }^{7}$.

It is known however that early analgesic approaches are able to decrease the incidence of CPOP, especially when effective management measures, such as epidural analgesia, are used $^{8,12}$. CPOP has often a neuropathic component, which makes its management more complex ${ }^{18}$. Unfortunately, many anesthesiologists, according to our results, are not aware of this fact, since just $23.7 \%$ of respondents have correctly answered that adequate acute pain management decreases the incidence of CPOP.

While the vast majority of respondents have stated that acute POP is well managed in their institutions, literature data have identified that inadequate management of this pain is common ${ }^{9,10}$. And even after the consolidation of the North-American hospital accreditation Joint Commission from 2001, which includes pain evaluation and management, there have been no significant changes in the way POP is managed in the United States?

Apfelbaum et al. ${ }^{9}$ have observed that from a sample of 250 surgical adult patients, $80 \%$ had pain (among them $86 \%$ moderate to severe pain, especially after hospital discharge), while $25 \%$ of the sample has complained of adverse effects related to the use of analgesics. Surprisingly, 90\% of these patients were happy with the treatment they received and, although being a mandatory procedure in American institutions, just $2 / 3$ of professionals have effectively evaluated patients' pain?

According to answers to this survey, for most respondents the perception is that the percentage of people experiencing POP is just $30 \%$, which is totally in disagreement with the literature. The perception of such professionals could be related to the fact that they have little contact with patients after anesthetic induction, particularly in the wards, and as a consequence, are not familiar with pain management ${ }^{9}$.

When asked about possible patients concerns before being submitted to surgery, most respondents have answered "feeling pain during surgery" and, secondly, fear of "feeling pain after surgery". Data of two different studies, however, show that most patients have as major concerns, respectively, "feeling pain after surgery" and "possibility of not getting better from the disease" which is the reason for the surgery ${ }^{9,10}$. In addition, Polomano et al. ${ }^{6}$ have stated that pain is the major reason for re-hospitalization and for delayed discharge in $36 \%$ of ambulatory surgeries and that $38 \%$ of readmitted patients are submitted to orthopedic surgeries.

Gandhi, Heitz \& Viscusi ${ }^{19}$ have reported possible factors contributing for inadequate acute postoperative pain management, which are opioid-induced hyperalgesia, previous chronic pain, tolerance to opioids, sickle cell anemia, drug abuse and also clinical and metabolic situations limiting the use of these analgesics. Other factors were related to physicians, such as fear of opioid adverse effects, of obstructive sleep apnea, of using opioids in the elderly (impaired cognition, kidney and liver functions limitation) and the idea of the inexistence of an optimal opioid ${ }^{19}$. All these factors are related to unpreparedness of multidisciplinary teams which are poorly trained in POP management.

Another common concern associated to POP management is the incidence of postoperative ileus, which is a major challenge during POP management. Most respondents have answered that encouraging patients to walk may contribute to decrease its duration. Postoperative ileus pathophysiology is based on several factors: psychological stress and sympathetic hyperactivity resulting in increased circulating catecholamines; inflammatory response, with mediators release by neutrophyls which interact and decrease the activity of intestinal neuromuscular junction neurotransmitters; and the influence of halogenated and surgical aggression on intestinal myoelectric activity ${ }^{20}$. Endogenous opioids, on the other hand, are increased in laparotomies, which contributes for longer postoperative ileus duration ${ }^{20}$. In addition, systemic or epidural morphine may also prolong postoperative ileus duration ${ }^{23}$. Most respondents, however, do not consider this a problem, once more showing unawareness or poor familiarity with POP management.

As to factors to be considered when choosing analgesics and doses, most respondents have correctly answered that physical status, surgery size and topography are important. It is known that there is further analgesic demand with major surgeries and when topography affects the chest (non cardiac and cardiac surgeries) and upper abdomen ${ }^{22,24}$. Age, physical status and weight also influence analgesic demand ${ }^{21}$. For major surgeries there is the need for more potent analgesics in the first 24 hours, such as opioids, and the need for more elaborated techniques, such as epidural ${ }^{25}$.

Still with regard to pain management, most respondents have answered that the use of analgesics "if needed" should be avoided for acute pain. This scheme may result in inflexibility of treatment, dependence on the nursing and medical team, peaking in delay to receive analgesics and, finally inadequate pain management, especially with regard to major surgeries ${ }^{23}$. The first category of analgesics remembered for management were non-opioid and non anti-inflammatory drugs (e.g. dipirone). There are many advantages of the use of combined therapy with non-steroid anti-inflammatory drugs and opioids, with lower dose of the latter ${ }^{24,25}$. In addition, there are less opioid-related adverse effects and, when selective cyclooxygenase type 2 agents (COX-2) are prescribed, there is no interference with bleeding time. The prescription of these agents may hasten oral ingestion, ambulation and discharge, in addition to decreasing pain at movement ${ }^{24,25}$.

However, opioids are still the most important armamentarium for acute postoperative moderate to severe pain management ${ }^{7,26}$, while locoregional blocks ${ }^{7}$, including continuous epidural $^{11,12}$, are the most effective routes for acute postoperative pain management, but these facts were not reported by respondents.

This study has bias and limitations, since sample was obtained among enrolled in an event, which attracts people interested in the exposed subject, and due to the fact of not 
knowing time of professional graduation and, as a consequence, how many participants are residents. We have also no demographic data, such as age and gender. But, anyway, results are important since there is limited detailed information about the way in which POP is managed in our country. In addition, it is recognized that the questionnaire evaluates professionals' impression about their own work, but does not objectively measure the performance of services of different institutions.

\section{CONCLUSION}

Anesthesiologists are the best professionals to manage acute postoperative pain, but in Brazil they are still not inserted in this context. They show little interest and unawareness of simple issues regarding pain management. A change in medical residence programs could result, in the medium and long term, in different professional behavior regarding acute postoperative pain management.

Attachment 1. Questions asked through virtual questionnaire available in the SurveyMonkey website

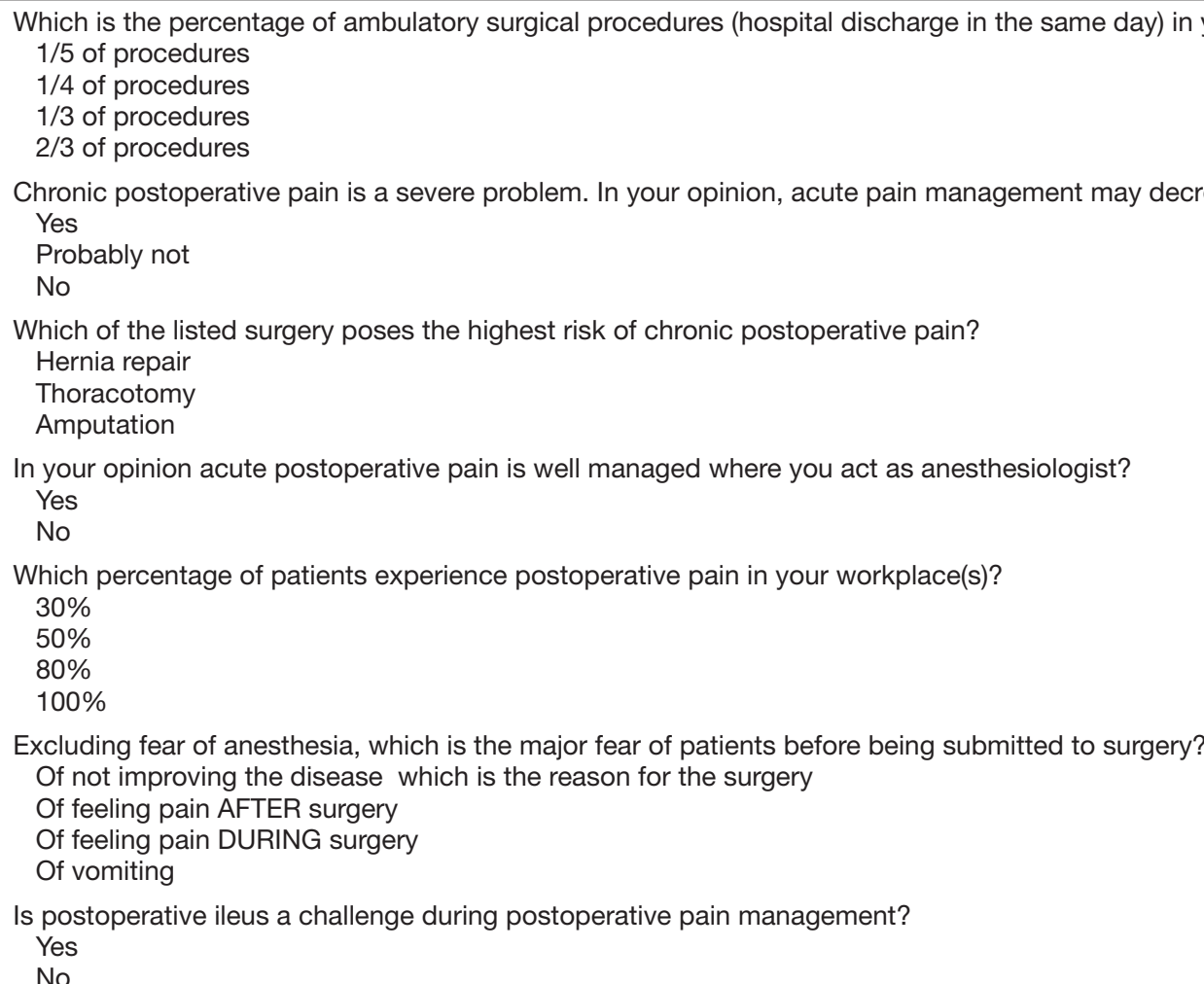

Which alternatives below have a factor which may shorten postoperative ileus duration?

Use of halogenated

Early prescription of opioids

Encouraging patient to walk

Let patient experience normal postoperative pain

What should be considered when choosing analgesics and their doses?

Surgery size

Surgical topography

Patient's physical status

age

all the above

In postoperative pain management, which should be the first analgesic to be remembered?

Non-opioid and non anti-inflammatory analgesic (e.g. dipirone)

Strong opioids (e.g. morphine)

Weak opioids (e.g. tramadol)

Non-selective non-steroid anti-inflammatory

Non-steroid selective Cox-2 inhibitor anti-inflammatory (e.g. parecoxib)

Others

With regard to the use "if needed" (SN) of analgesic drugs one may state:

Should be the choice for acute pain management

Offers Just the dose needed by patient, so it is safer and more effective

Should be avoided for acute pain

Should only be used for opioid prescription 
Attachment 1. Questions asked through virtual questionnaire available in the SurveyMonkey website - continuation

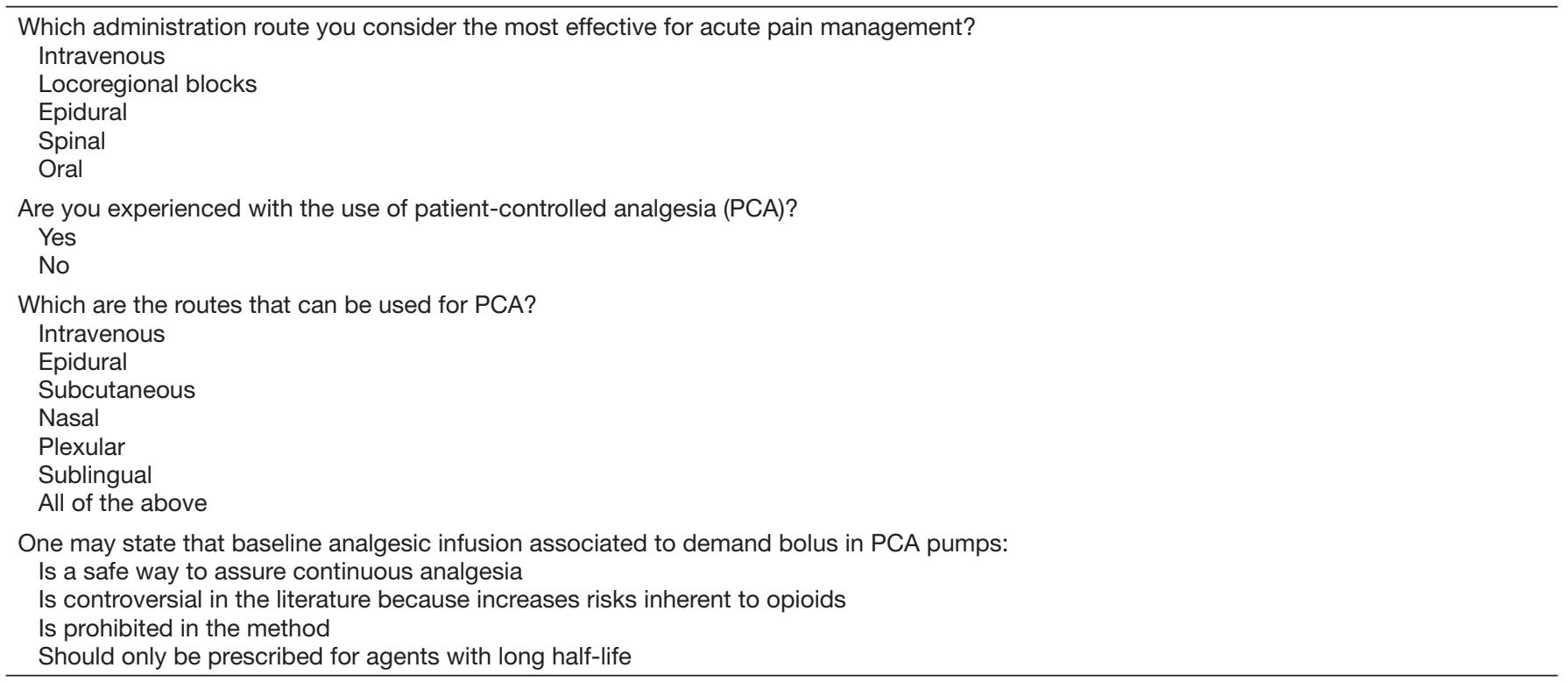

\section{REFERENCES}

1. McLeod GA, Davies HT, Colvin JR. Shaping attitudes to postoperative pain relief: the role of the acute pain team. J Pain Symptom Manage. 1995;10(1):30-4.

2. Albrecht E, Taffe P, Yersin B, Schoettker P, Decosterd I, Hugli O. Undertreatment of acute pain (oligoanalgesia) and medical practice variation in prehospital analgesia of adult trauma patients: a $10 \mathrm{yr}$ retrospective study. Br J Anaesth. 2013;110(1):96-106.

3. Argoff CE. Recent management advances in acute postoperative pain. Pain Pract. 2014;14(5):477-87.

4. Stalnikowicz R, Mahamid R, Kaspi S, Brezis M. Undertreatment of acute pain in the emergency department: a challenge. Int J Qual Health Care. 2005;17(2):173-6.

5. Carr DB, Goudas LC. Acute pain. Lancet. 1999;353(9169):2051-8.

6. Polomano RC, Dunwoody CJ, Krenzischek DA, Rathmell JP. Perspective on pain management in the $21^{\text {st }}$ century. Pain Manag Nurs. 2008;9(1 Suppl):S3-10.

7. Pamela EM, David AS, Stephan AS. Acute Pain Management: Scientific Evidence. $3^{\text {rd }}$ ed. Melbourne, Australian and New Zealand College of Anaesthetists; 2010. 1-540p.

8. Brown AK, Christo PJ, Wu CL. Strategies for postoperative pain management. Best Pract Res Clin Anaesthesiol. 2004;18(4):703-17.

9. Apfelbaum JL, Chen C, Mehta SS, Gan TJ. Postoperative pain experience: results from a national survey suggest postoperative pain continues to be undermanaged. Anesth Analg. 2003;97(2):534-40.

10. Warfield CA, Kahn CH. Acute pain management. Programs in U.S. hospitals and experiences and attitudes among U.S. adults. Anesthesiology.1995;83(5):1090-4.

11. Moon MR, Luchette FA, Gibson SW, Crews J, Sudarshan G, Hurst JM et al. Prospective, randomized comparison of epidural versus parenteral opioid analgesia in thoracic trauma. Ann Surg. 1999;229(5):684-91.

12. Sentürk M, Ozcan PE, Talu GK, Kiyan E, Camci E, Ozyalçin S, et al - The effects of three different analgesia techniques on long-term posthoracotomy pain. Anesth
Analg, 2002;94(1):11-5.

13. Kehlet H, Jensen TS, Woolf CJ. Persistent postsurgical pain: risk factors and prevention. Lancet. 2006;367(9522):1618-25.

14. McQuay HJ, Poon KH, Derry S, Moore RA. Acute pain: combination treatments and how we measure their efficacy. Br J Anaesth. 2008;101(1):69-76.

15. Ready LB, Edwards WT- Adult postoperative pain,em: Ready LB, Edwards WT. Management of acute pain: a practical guide, $1^{\text {st }}$ ed. Seatle: IASP Publications; 1992. 22-5p.

16. Cullen KA, Hall MJ, Golosinskiy A. Ambulatory surgery in the United States, 2006 Natl Health Stat Report. 2009;(11):1-25.

17. Marshall SI, Chung F. Discharge criteria and complications after ambulatory surgery. Anesth Analg. 1999;88(3):508-17.

18. Macrae WA. Chronic post-surgical pain: 10 years on. Br J Anaesth. 2008;101(1):77-86.

19. Gandhi K, Heitz JW, Viscusi ER. Challenges in acute pain management. Anesthesiol Clin. 2011; 29(2):291-309.

20. Luckey A, Livingston E, Tache Y. Mechanisms and treatment of postoperative ileus Arch Surg. 2003;138(2):206-14.

21. Preble LM, Guveyan JA, Sinatra RS. Patient characteristics influencing postoperative pain management. In: Sinatra RS, Hord AH, Giusberg B, et al. editors. Acute Pain: Mechanisms and Management. St. Louis: Mosby-Year Book; 1992. 140-50p.

22. Barros GA, Lemonica L. Patient controlled analgesia in a university hospital. Br J Anaesth. 2003;53(1):69-82.

23. Owen H, McMillan V, Rogowski D. Postoperative pain therapy: a survey of patients' expectations and their experiences. Pain. 1990;41(3):303-7.

24. Buvanendran A, Kroin JS. Multimodal analgesia for controlling acute postoperative pain. Curr Opin Anaesthesiol. 2009;22(5):588-93.

25. Jin F, Chung F. Multimodal analgesia for postoperative pain control. J Clin Anesth. 2001;13(7):524-39.

26. White PF. The changing role of non-opioid analgesic techniques in the management of postoperative pain. Anesth Analg. 2005;101(5 Suppl):S5-22. 